\title{
Effects of Processing Methods on Nutrient Retention of Processed Okro (Abelmoschus Esculentus) Fruit
}

\author{
Adepoju, Oladejo $\mathrm{T}^{1} \&$ Adefila, Samuel $\mathrm{A}^{1}$ \\ ${ }^{1}$ Department of Human Nutrition, Faculty of Public Health, College of Medicine, University of Ibadan, Ibadan \\ Nigeria \\ Correspondence: Department of Human Nutrition, Faculty of Public Health, College of Medicine, University of \\ Ibadan, Ibadan Nigeria. E-mail: tholadejo@yahoo.com
}

Received: July 2, 2015 Accepted: September 13, 2015 Online Published: November 11, 2015

doi:10.5539/jfr.v4n6p62 URL: http://dx.doi.org/10.5539/jfr.v4n6p62

\begin{abstract}
Non-leafy vegetables are highly perishable products and require good processing treatment to prevent post harvest losses. The common traditional method of their preservation is sun-drying or blanching followed by sun-drying. Okro fruit is generally preserved through sun-drying in Nigeria with little documentation on its nutrient retention. This study was therefore carried out to determine effects of processing methods on micronutrient retention of processed okro. Okro fruit was purchased from Bodija market, Ibadan and divided into three portions treated as raw, sun-dried, and blanched/sun-dried samples. Market sun-dried sample was purchased from the market for comparison. The four samples were analysed for proximate, mineral and vitamin composition using standard methods of AOAC, atomic absorption spectrophotometric and spectrophotometric methods. Edible portion of $100 \mathrm{~g}$ of fresh sample contained $84.5 \mathrm{~g}$ moisture, $2.9 \mathrm{~g}$ crude protein, $0.2 \mathrm{~g}$ lipid, $2.1 \mathrm{~g}$ ash, $8.3 \mathrm{~g}$ carbohydrate, $46.47 \mathrm{mg}$ sodium, $102.27 \mathrm{mg}$ potassium, $86.37 \mathrm{mg}$ calcium, $64.80 \mathrm{mg}$ phosphorus, $11.40 \mathrm{mg}$ magnesium, $1.63 \mathrm{mg}$ iron, $3.70 \mathrm{mg}$ zinc, and yielded $41.13 \mathrm{kcal}$ of energy. Market sun-dried sample had the highest value of ash and carbohydrate while blanched sun-dried sample had highest gross energy $(p<0.05)$. Fresh okro sample had the highest ascorbic acid $(33.02 \mathrm{mg})$ and lowest $\beta$-carotene $(196.57 \mu \mathrm{g})$ values $(\mathrm{p}<0.05)$. The calcium, phosphorus, magnesium, copper and manganese content of sun-dried sample was significantly higher than other samples $(\mathrm{p}<0.05)$ while market sample was significantly higher in sodium, potassium, iron and zinc value compared with fresh, blanched sun-dried and sun-dried samples $(\mathrm{p}<0.05)$. Sun-drying seemed to be the better method of okro preservation to retain most micronutrients.
\end{abstract}

Keywords: okro fruit, nutrient retention, sun-drying, blanching

\section{Introduction}

Fruits and vegetables consumption is beneficial because, in addition to macronutrients, they contain vitamins, minerals and trace elements, fibre and some food energy, as well as antioxidants and many other complex plants components called phytochemicals. Leafy and non leafy vegetables are desirable component of human diet as they provide a range of required nutrients and they constitute important component of diets in many Nigerian homes. Apart from adding variety to menu, they add flavor, taste, colour and aesthetic appeal to what would otherwise be a monotonous diet. They also serve as sources of important nutrients such as protein, minerals and vitamins, as well as fibre, which are usually in short supply in daily diets of consumers, especially in rural areas (Mepha et al., 2007).

Vegetables are rich sources of beta-carotene, the B-vitamins and vitamin C. They also contain some calcium, phosphorous, potassium sodium, magnesium, zinc, and trace amount of iron (Ihekoronye, 1985). Studies on the Nutritional Status in Nigeria have shown the existence of major micronutrient deficiencies (vitamin A, iodine and iron, (NDHS, 2013). In Nigeria, the mainly grown non leafy vegetables include tomato, okro, sweet pepper, and carrot. Among these, okro is the more commonly consumed by all classes in sauces and soups, and is a good source of vitamins (Habtamu et al., 2014). However, vegetable production is seasonal, being in much abundance during the rainy season but in short supply during dry season.

Okro is a widely cultivated and consumed non leafy vegetable in tropical and sub tropical centers. It is a source of protein, vitamin $\mathrm{C}$ and beta carotene (which is a pro-vitamin A), iron and calcium and dietary fibre (Habtamu et al., 2014). It contains large quantities of glycine which is responsible for the viscosity of aqueous suspension 
and the strongly gum like consistency that is particularly desirable in soups (Owoeye, 1990; Kendall \& Jenkins, 2004).

Because of its high moisture content and respiratory activities, Okro is highly perishable, leading to increased post harvest loss due to poor storage facilities or preservation method. Processing and storage of foods have become integral parts of modern day food chain, and seasonal produce are processed and preserved during the peak harvest to reduce post harvest loss and making the products available all year round (Sagar \& Suresh, 2010). Proper processing and preservation methods are essential in producing okro products of high market and nutritive value (Ihekoronye, 1985).

The most common method employed in preserving okro in many homes in Nigeria is sun drying. Processing such as sun drying, blanching and then sun drying may have considerable effects on the nutritive and sensory values of final products. Little has been reported on processing and preservation methods that enhance micronutrient retention of okro in the literature, hence this study was carried out to evaluate the nutrient retention level of various processing methods of preservation of okro fruit.

\section{Materials and Methods}

\subsection{Sample Collection and Preparation}

Fresh okro fruits and sundried product were randomly purchased from four stalls in Bodija market, a major farm market in Ibadan when in season. The fresh okro fruit was sliced and thoroughly mixed to form homogenized sample. Five hundred grammes $(500 \mathrm{~g})$ of the sliced okro was weighed and labelled as fresh okro (Sample 1). Another $500 \mathrm{~g}$ portion was dipped in boiling at $100^{\circ} \mathrm{C}$ for 5 minutes and sundried in a tray in an open space to constant weight (2 weeks), and labelled as Sample 2; while another $500 \mathrm{~g}$ portion was sundried to constant weight ( 2 weeks) in a tray in an open space and labelled as Sample 3. Market sundried product (Sample 4) served as control. The four samples were analysed chemically in triplicates as follows.

\subsection{Proximate Composition Analysis}

Moisture content of the two samples was determined by air oven method (Gallenkamp, Model OV - 440, England) at $105^{\circ} \mathrm{C}$ (AOAC, 2005: (967.08)). The crude protein of the samples was determined using micro-Kjeldahl method (AOAC, 2005: (988.05)). Crude lipid was determined by soxhlet extraction method (AOAC, 2005: (2003.06)). The ash content was determined by weighing $5 \mathrm{~g}$ of sample in triplicate and heated in a muffle furnace at $550^{\circ} \mathrm{C}$ for $4 \mathrm{~h}(\mathrm{AOAC}, 2005:(942.05))$. The carbohydrate content was obtained by difference. Gross energy of the samples was determined using ballistic bomb calorimeter (Manufacturer: Cal 2k- Eco, TUV Rheinland Quality Services (Pty) Ltd, South Africa).

\subsection{Mineral Analysis}

Potassium and sodium content of the samples were determined by digesting the ash of the samples with perchloric acid and nitric acid, and then taking the readings on Jenway digital flame photometer/spectronic20 (AOAC, 2005: (975.11)). Phosphorus was determined by vanado-molybdate colorimetric method (AOAC, 2005: (975.16)). Calcium, magnesium, iron zinc, manganese, copper and selenium were determined spectrophotometrically, by using Buck 200 atomic absorption spectrophotometer (Buck Scientific, Norwalk) and compared with absorption of standards of these minerals (AOAC, 2005: (975.23)).

\subsection{Vitamin Analysis}

\subsubsection{Beta carotene determination}

Beta carotene ( $\beta$-carotene) was determined through ultraviolet absorption measurement at $328 \mathrm{~nm}$ after extraction with chloroform. Calibration curve of $\beta$-carotene was made and the sample $\beta$-carotene concentration estimated as microgram $(\mu \mathrm{g})$ of $\beta$-carotene (AOAC, 2005 (1893)).

\subsubsection{Ascorbic Acid Determination}

Ascorbic acid in the sample was determined by titrating its aqueous extract with solution of 2, 6-dichlorophenol-indophenol dye to a faint pink end point (AOAC, 2005, (1893)).

\subsection{Data Analysis}

The data obtained was analysed statistically using analysis of variance (ANOVA) and the level of significance set at $\mathrm{p}<0.05)$. 


\section{Results}

\subsection{Proximate Composition of Okro Fruit}

The result of proximate composition of fresh and processed okro samples is shown in Table 1. Fresh okro was very high in moisture content. The sundried samples were very low in moisture content, and their values significantly differed from each other $(p<0.05)$. The fresh okro and its dried products were very low in crude protein, the fresh sample having the highest value while blanched sundried okro had the least. There was no significant difference between the crude protein of blanched sundried (Sample 2) and sundried okro (Sample 3), $(\mathrm{p}>0.05)$. The value of crude protein of market sample (Sample 4) was insignificantly higher than the experimental sundried sample (Sample 3).

Table 1. Proximate composition of fresh and processed Okro (g/100g)*

\begin{tabular}{lrrrr}
\hline Sample & 1 & 2 & 3 & 4 \\
\hline Moisture & $84.53 \pm 0.05^{\mathrm{a}}$ & $15.20 \pm 0.04^{\mathrm{b}}$ & $14.06 \pm 0.03^{\mathrm{c}}$ & $13.35 \pm 0.03^{\mathrm{d}}$ \\
Crude protein & $2.92 \pm 0.01^{\mathrm{a}}$ & $2.69 \pm 0.02^{\mathrm{b}}$ & $2.70 \pm 0.01^{\mathrm{b}}$ & $2.74 \pm 0.09^{\mathrm{b}}$ \\
Crude lipid & $0.17 \pm 0.00^{\mathrm{a}}$ & $1.55 \pm 0.01^{\mathrm{b}}$ & $1.54 \pm 0.01^{\mathrm{b}}$ & $1.54 \pm 0.02^{\mathrm{b}}$ \\
Ash & $0.41 \pm 0.00^{\mathrm{a}}$ & $1.36 \pm 0.00^{\mathrm{b}}$ & $1.43 \pm 0.01^{\mathrm{c}}$ & $1.49 \pm 0.02^{\mathrm{c}}$ \\
Total Carbohydrate & $10.26 \pm 0.04^{\mathrm{a}}$ & $79.19 \pm 0.07^{\mathrm{b}}$ & $80.28 \pm 0.01^{\mathrm{b}}$ & $78.28 \pm 0.06^{\mathrm{b}}$ \\
Gross energy (kcal/) & $41.13 \pm 1.53^{\mathrm{a}}$ & $285.47 \pm 1.16^{\mathrm{b}}$ & $282.17 \pm 1.16^{\mathrm{b}}$ & $283.96 \pm 1.15 \mathrm{~b}$ \\
\hline
\end{tabular}

* Values are means and standard deviation of three determinations.

Values with the same superscript are not significantly different while those with different superscripts are significantly different from each other

Sample 1 = Fresh okro, Sample 2 = Blanched sundried okro,

Sample 3 = Experimental sundried okro, Sample 4 = Market sundried okro

Blanched sundried okro had the highest crude lipid value while the fresh sample (Sample 1) had the lowest. There was no significant difference in crude lipid value of experimental sundried and market sundried samples. The ash content of the fresh sample was significantly higher than the blanched sundried, experimental sundried and market samples $(\mathrm{p}<0.05)$. There was no significant difference between the ash value of experimental and market samples, but their values were significantly higher than that of blanched sundried sample (Sample 2) $(p<0.05)$. There were no significant difference in total carbohydrates and gross energy content of Samples 2, 3, and 4, which were significantly higher than that of fresh sample (Sample 1) $(\mathrm{p}<0.05)$.

\subsection{Mineral and Vitamin Composition of Okro Fruit}

The result of the mineral and selected vitamin composition of fresh and processed okro samples are shown in Table 2. The market sample (Sample 4) was highest in potassium, sodium and $\beta$-carotene content, Sample 3 was highest in calcium, magnesium and phosphorus, while sample 2 was highest in iron, zinc and copper. Sample 1 was lowest in all the micronutrients except vitamin C. The mineral content of Samples 3 and 4 were closely related and significantly higher than that of samples 1 and $2(p<0.05)$.

Blanched sundried sample had the highest zinc value while the fresh sample had the lowest. Market sample zinc value was significantly higher than the experimental and fresh samples but significantly lower than the blanched sample $(\mathrm{p}<0.05)$. The beta carotene content of Sample 2 was closely related to that of Sample 1 but are significantly lower than that of Samples 3 and 4 ( $p<0.05)$, which were almost the same value. 
Table 2. Mineral and selected vitamin composition of fresh and processed Okro (mg/100g)*

\begin{tabular}{lrrrr}
\hline Sample & 1 & 2 & 3 & 4 \\
\hline Potassium & $102.27 \pm 0.12^{\mathrm{a}}$ & $346.50 \pm 0.00^{\mathrm{b}}$ & $348.70 \pm 0.17^{\mathrm{b}}$ & $354.40 \pm 0.20^{\mathrm{b}}$ \\
Sodium & $46.47 \pm 0.25^{\mathrm{a}}$ & $105.20 \pm 0.12^{\mathrm{b}}$ & $112.60 \pm 0.17^{\mathrm{c}}$ & $116.20 \pm 0.12^{\mathrm{c}}$ \\
Calcium & $86.37 \pm 0.15^{\mathrm{a}}$ & $156.50 \pm 0.17^{\mathrm{b}}$ & $165.50 \pm 0.20^{\mathrm{c}}$ & $162.40 \pm 0.25^{\mathrm{c}}$ \\
Magnesium & $11.40 \pm 0.17^{\mathrm{a}}$ & $92.80 \pm 0.30^{\mathrm{b}}$ & $102.70 \pm 0.40^{\mathrm{c}}$ & $96.33 \pm 0.15^{\mathrm{b}}$ \\
Phosphorus & $64.80 \pm 0.30^{\mathrm{a}}$ & $302.50 \pm 0.12^{\mathrm{b}}$ & $318.53 \pm 0.15^{\mathrm{c}}$ & $316.30 \pm 0.12^{\mathrm{c}}$ \\
Iron & $1.63 \pm 0.12^{\mathrm{a}}$ & $11.43 \pm 0.12^{\mathrm{b}}$ & $9.30 \pm 0.17^{\mathrm{c}}$ & $9.53 \pm 0.12^{\mathrm{c}}$ \\
Zinc & $3.70 \pm 0.17^{\mathrm{a}}$ & $12.17 \pm 0.12^{\mathrm{b}}$ & $11.23 \pm 0.12^{\mathrm{b}}$ & $11.63 \pm 0.12^{\mathrm{b}}$ \\
Manganese & $5.33 \pm 0.12^{\mathrm{a}}$ & $13.40 \pm 0.17^{\mathrm{b}}$ & $14.23 \pm 0.12^{\mathrm{c}}$ & $13.93 \pm 0.15^{\mathrm{c}}$ \\
Copper & $0.90 \pm 0.17^{\mathrm{a}}$ & $3.97 \pm 0.23^{\mathrm{b}}$ & $3.60 \pm 0.17^{\mathrm{c}}$ & $3.33 \pm 0.12^{\mathrm{d}}$ \\
Beta-carotene $(\mu \mathrm{g} /)$ & $196.57 \pm 0.23 \mathrm{a}$ & $198.20 \pm 0.36^{\mathrm{a}}$ & $237.17 \pm 0.25^{\mathrm{b}}$ & $238.47 \pm 2.31^{\mathrm{b}}$ \\
Ascorbic Acid & $33.02 \pm 0.30^{\mathrm{a}}$ & $12.82 \pm 0.05^{\mathrm{b}}$ & $17.35 \pm 0.04^{\mathrm{c}}$ & $15.56 \pm 0.07^{\mathrm{d}}$ \\
\hline
\end{tabular}

* Values are means and standard deviation of three determinations.

Values with the same superscript are not significantly different while those with different superscripts are significantly different from each other

Sample 1 = Fresh okro, Sample 2 = Blanched sundried okro,

Sample 3 = Experimental sundried okro, Sample 4 = Market sundried okro

\section{Discussion}

\subsection{Proximate Composition}

The moisture content of fresh okro was close to the value reported for fresh okro in the literature (Victory, 1979). Fruits and vegetables are generally high in moisture content. High moisture content in the vegetables is an indication of easy susceptibility to microbial spoilage and low shelf life. The significant reduction in moisture content of the products was desirable in order to arrest the process of microbial spoilage and increase the shelf life of the products. The values obtained for the moisture content of the processed samples was very close to that of the market sample. The slight difference in moisture values might have resulted from longer keeping period before the purchase of the market sample (Sample 4) (which could not be determined), compared with the freshly prepared laboratory samples (Samples 2 and 3).

Fruits and vegetables are poor sources of plant protein, and hence are not consumed for the purpose of meeting protein needs of consumers. However, the protein content of fresh okro was higher than the values reported for okra by Habtamu et al., (2014) (2.1 g/100g sample). The amino acid composition of okra seed protein has been reported to be comparable to that of soybean and the protein efficiency ratio higher than that of soybean (Adetuyi et al., 2012) and its amino acid pattern renders it an adequate supplement to legume or cereal based diets (Ndangui et al., 2010). Its seed protein has also been reported to be rich in high quality protein especially with regards to its essential amino acids content relative to other plant protein sources (National Academic Council, 2006), hence, it can play a vital role in the human diet (Farinde et al., 2007).

There was slight reduction in the value of protein for the products, Sample 2 recording higher reduction than Sample 3. Nutrient loss through soaking and cooking food items in water has been reported (Bradbury et al., 1998; Adepoju et al., 2010), hence the higher reduction level in blanched sundried product. The higher reduction level of protein in blanched sundried sample is suggestive of loss of protein through leaching into the blanching water, indicating that the okro contained water soluble protein. No clear explanation can be offered for significant reduction in protein content experienced by sundried sample (Sample 3).

The crude lipid value of fresh okro agrees with the reported value for fresh okro in the literature (USDA, 2011). The low level of crude lipid in the fresh okro is indicative of its being a poor source of fat soluble vitamins. Sun drying resulted in significant increase in the crude lipid content of the dried samples $(p<0.05)$. This significant increase was attributable to reduction in moisture content of the sundried samples, thereby increasing the concentration of nutrients (Barnett \& Burrow, 2004). The values obtained for blanched sundried sample (Sample 
2) was insignificantly higher than that of experimental sundried sample (Sample 3). There was no significant difference in the experimental sundried samples compared with the market sample (Sample 4), (p>0.05).

Blanching and sun drying brought significant increase in the ash content of the processed samples. The observed significant increase in ash content of the products was believed to be due to significant reduction in moisture content of fresh sample. Blanching resulted in significant reduction in the ash content of Sample 2 compared with Sample 3. Market sample was insignificantly higher than the experimental sundried sample. Fresh okro was low in crude fibre and carbohydrates but reduction in moisture content brought significant increase in their values $(\mathrm{p}<0.05)$. The crude fibre value of the experimental sample was higher than that of the market sample. No possible reason(s) can be adduced to this observation. The carbohydrate content of both experimental and market samples were very similar.

Table 3. Mineral and selected vitamin composition of fresh and processed Okro (mg/100g)

\begin{tabular}{lrrrr}
\hline Sample & 1 & 2 & 3 & 4 \\
\hline Potassium & $102.27 \pm 0.12$ & $346.50 \pm 0.00$ & $348.70 \pm 0.17$ & $354.40 \pm 0.20$ \\
Sodium & $46.47 \pm 0.25$ & $105.20 \pm 0.12$ & $112.60 \pm 0.17$ & $116.20 \pm 0.12$ \\
Calcium & $86.37 \pm 0.15$ & $156.50 \pm 0.17$ & $165.50 \pm 0.20$ & $162.40 \pm 0.25$ \\
Magnesium & $11.40 \pm 0.17$ & $92.80 \pm 0.30$ & $102.70 \pm 0.40$ & $96.33 \pm 0.15$ \\
Phosphorus & $64.80 \pm 0.30$ & $302.50 \pm 0.12$ & $318.53 \pm 0.15$ & $316.30 \pm 0.12$ \\
Iron & $1.63 \pm 0.12$ & $11.43 \pm 0.12$ & $9.30 \pm 0.17$ & $9.53 \pm 0.12$ \\
Zinc & $3.70 \pm 0.17$ & $12.17 \pm 0.12$ & $11.23 \pm 0.12$ & $11.63 \pm 0.12$ \\
Manganese & $5.33 \pm 0.12$ & $13.40 \pm 0.17$ & $14.23 \pm 0.12$ & $13.93 \pm 0.15$ \\
Copper & $0.90 \pm 0.17$ & $3.97 \pm 0.23$ & $3.60 \pm 0.17$ & $3.33 \pm 0.12$ \\
Beta-carotene $(\mu \mathrm{g} /)$ & $196.57 \pm 0.23$ & $198.20 \pm 0.36$ & $237.17 \pm 0.25$ & $238.47 \pm 2.31$ \\
Ascorbic Acid & $33.02 \pm 0.30$ & $12.82 \pm 0.05$ & $17.35 \pm 0.04$ & $15.56 \pm 0.07$ \\
\hline
\end{tabular}

Sample 1 = Fresh okro, Sample 2 = Blanched sundried okro, Sample $3=$ Experimental sundried okro Sample $4=$ Market sundried okro.

\subsection{Mineral and Selected Vitamin Composition}

Fresh okro sample was low in copper, sodium, phosphorus and iron content but moderate in potassium, calcium, zinc and manganese (Table 3). The value obtained for calcium and potassium was in agreement with those reported in the literature (Osunde, 2007; USDA, 2011). Reduction in moisture content resulted in significant increase in value of all minerals. Blanching before sun drying resulted in significant reduction in sodium, calcium, magnesium, phosphorus and manganese content of Sample 2 compared with Sample 3, while Sample 2 was significantly higher in iron, zinc, and copper content $(\mathrm{p}<0.05)$. Experimental sundried sample (Sample 3 ) was insignificantly higher in calcium, magnesium phosphorus, manganese and copper content than the market sample, while market sample (Sample 4) was insignificantly higher in potassium, sodium, iron, and zinc content.

The moderately high potassium and low sodium content of fresh okro is an advantage for the fruit to serve as soup ingredient which can be consumed by the hypertensives. High potassium and low sodium combination is a good choice for the intra and extra cellular fluid balance in the body system (Roth \& Townsend, 2003), hence, consumption of fresh okro or its product by the hypertensives is advantageous. The level of calcium, phosphorus, zinc and manganese qualify okro as good source of these micronutrients.

Calcium is needed for normal nerve and muscle action, blood clotting, heart function and cell metabolism, and in combination with phosphorus, is a component of bones and teeth to give strength and hardness (Roth \& Townsend, 2003; Rolfe et al., 2007). Zinc is important as a co-factor for enzymes, essential for growth (especially in children), wound healing, taste acuity, glucose tolerance, and mobilization of vitamin A in the body (Roth \& Townsend, 2003). Copper is an essential component of several enzymes, it helps in haemoglobin formation, aids in transport of iron to the bone marrow for formation of red blood cells, and participates in energy production; while manganese is a constituent of several enzymes involved in metabolism, and is important in bone formation (Roth \& Townsend, 2003). The level of both macro and micro minerals in fresh and 
sundried okro imply that okro and its product can assist in meeting substantial part of mineral requirements of its consumers.

The value of fresh okro for beta carotene and ascorbic acid was in agreement with the literature (Osunde et al., 2007; USDA, 2011). Fresh okro was high in beta carotene and ascorbic acid. Sun drying resulted in significant increase in the beta carotene content while it brought significant reduction in the value of ascorbic acid. Blanching and then sun drying resulted in slight insignificant increase in beta carotene content of the product with significant loss in ascorbic acid $(\mathrm{p}<0.05)$. Sun drying generally brought significant increase in value of beta carotene with significant reduction in ascorbic acid content $(\mathrm{p}<0.05)$ in the sundried products (Samples 2 and 3 ). Sample 4 had the highest value of beta carotene while Sample 1 had the least.

Beta carotene is important as pro-vitamin A for the maintenance of normal tissue structure and other important physiological functions such as vision and reproduction (Shubhangini, 2002; Habtamu et al., 2014). The ascorbic acid content of fresh and sundried okro was higher than the values reported for native pear $(11.28 \mathrm{mg}, 3.82 \mathrm{mg}$ and $6.75 \mathrm{mg} / 100 \mathrm{~g}$ for fresh, roasted, and steamed samples respectively, Adepoju \& Adeniji, 2008), but lower than the value reported by Habtamu et al. (2014). The values of beta carotene and ascorbic acid content of fresh okro qualify it as a good source of antioxidants.

\section{Conclusion}

Fresh okro and its dried products were high in mineral content and beta carotene, especially the experimental sundried sample (Sample 3) which was highest in calcium, phosphorus, magnesium, copper, and manganese. The value of nutrient content of processed okro samples were closely related to that of the market sample, showing good preparation methods for the laboratory samples. Blanching led to loss of nutrients, especially minerals and vitamins in the processed product. Sun drying led to significant loss in ascorbic acid content of the dried samples. The ratio of combination of sodium and potassium in raw and processed okro qualifies them as good soup ingredient for the hypertensives, while its micronutrient composition makes it suitable for all, hence, their consumption should be encouraged.

\section{References}

Adepoju O. T., \& Adeniji, P. O. (2008). Nutrient Composition, antinutritional factors and contribution of native pear (Dacryoides edulis) pulp to nutrient intake of consumers. Nigerian Journal of Nutritional Sciences, 29(2), 15-23.

Adepoju, O. T., Adekola, Y. G., Mustapha, S. O., \& Ogunola, S. O. (2010). Effect of processing methods on nutrient retention and contribution of local diets from cassava (Manihot spp) to nutrient intake of Nigerian consumers. African Journal of Food Agriculture, Nutrition and Development (AJFAND), 10(2), 2099-2111.

Adetuyi, F., Ajala, L., \& Ibrahim, T. (2012). Effect of the addition of defatted okra seed (Abelmoschus esculentus) flour on the chemical composition, functional properties and zinc bioavailability of plantain (musa paradisiacal linn) flour. JMBFS, 2(1), 69-82.

AOAC. (2005). Association of Official Analytical Chemists Official methods of Analysis of AOAC International. Gaithersburg, MD. USA.

Barnett, M. A. A., \& Burrow, O. (2004). Effect of processing on nutrient content of food (article 37:160-164).

Bradbury, J. H., Bradshaw, K., Jealous, W., Holloway, W. D., \& Phimpisame, T. (1998). Effect of cooking on nutrient content of tropical root crops from the South Pacific. Journal of Science of Food \& Agriculture, 43, 333-342. http://dx.doi.org/10.1002/jsfa.2740430406

Farinde, A., Owolarafe, O., \& Ogungbemi, I. (2007). An overview of production, processing, marketing and utilisation of okra in Egbedore LOCAL government Area of Osun State, Nigeria. Agricultural Engineering, $4,1-17$.

Habtamu, F. G., Negussie, R., Gulelat, D. H., \& Ashagrie, Z. W. (2014). Nutritional quality and health benefits of okra (Abelmoschus Esculentus): A Review. Global Journal of Medical Research, 14(5), 28-37.

Ihekoronye, A. I., \& Ngoddy, P. O. (1985). Integrated food science and nutrition for the tropics (pp. 144-306). Macmallian, London, England..

Kendall, C. W. C., \& Jenkins, D. J. A. (2004). A dietary portfolio: maximal reduction of low-density lipoprotein cholesterol with diet. Current Atherosclerosis Reports, 6, $492-498$. http://dx.doi.org/10.1007/s11883-004-0091-9

Mepba, H. D., Eboh, L., \& Banigo, D. E. B. (2007). Effect of processing treatments on the nutritive composition 
and consumer acceptance of some Nigeria edible leafy vegetable. African Journal of Food Agriculture, Nutrition and Development, 7(1), 1-18.

National Research Council. (2006). "Okra". Lost Crops of Africa: Volume II: Vegetables. Lost Crops of Africa. 2. National Academies Press. ISBN: 0-309-66582-5.

Ndangui, C. B., Kimbonguila, A., Nzikou, J. M., Matos, L., Pambou, N. P. G., Abena, A., ... De sobry, S. (2010). Nutritive composition and properties physico-chemical of gumbo (Abelmoschus esculentus L.) seed and oil. Research Journal of Environmental and Earth Sciences, 2(1), 49-54.

NDHS. (2013). Nigeria Demographic and Health Survey 2013. National Population Commission Federal Republic of Nigeria, Abuja, Nigeria; ICF International Rockville, Maryland, USA June 2014.

Ologhobo, A. D., \& Fetuga, B. L. (1983). Investigation on the trypsin inhibitor, hemagglutinin,phytic and tannic acid contents of cowpea Vigna Unguiculata. Food Chemistry, 12(4), 249-254. http://dx.doi.org/10.1016/0308-8146(83)90013-4

Sagar, V. R., \& Suresh, K. P. (2010). Recent advances in drying and dehydration of fruits and vegetables: A review. Journal of Food Science and Technology, 47(1), 15-26. http://dx.doi.org/10.1007/s13197-010-0010-8

Shubhangini, A. J. (2002). Nutrition and dietetics (2nd Ed., pp. 93-94).

USDA. (2011). National Nutrient Database for Standard Reference Release 27. Retrieved from http://ndb.nal.usda.gov/ndb/foods/show $/ 3061$ ? manu= $\&$ fgcd=

WHO/FAO. (2003). Report of a joint WHO/FAO Expert Consultation on Diet, Nutrition and prevention of Chronic Diseases. WHO Technical Report Series \#916.

\section{Copyrights}

Copyright for this article is retained by the author(s), with first publication rights granted to the journal.

This is an open-access article distributed under the terms and conditions of the Creative Commons Attribution license (http://creativecommons.org/licenses/by/3.0/). 